\title{
学童の咽頭分離 $\mathrm{A}$ 群溶血レンサ球菌
}

\section{(Streptococcus pyogenes) の動態}

\section{第 1 編 16年間（1962 1977）の菌型の推移}

\author{
猩紅熱研究会 \\ 大阪市立少年保養所 \\ （前大阪市立桃山病院） \\ 中 島 邦夫 \\ 大阪市立桃山病院 \\ 足立利幸羽田回
}

（昭和54. 2. 20受付）

（昭和54.4.17受理）

Key words: $M$ types of group A-hemolytic streptococci, Schoolchildren, Scarlet fever patients

\section{I. 緒 言}

溶血レンサ球菌感染症として咽頭炎, 扁桃炎を 始め化膿性皮膚疾患や，猩紅熱等，さらには急性 系球体腎炎, リウマチ熱等多くの疾患があるが, その大部分は $\mathrm{A}$ 群に起因するものである。

しかし, 溶血レンサ球菌は, 臨㦿的には何等の症 状も呈さない一般の健康人, 特に学童の咽頭から もしばしば分離されることは既知の事実である。

我々は大阪市内の 2 ケ所の小学校の健康学童を 対象に, 16年間にわたつて, 咽頭よりA 群溶血レ ンサ球菌の分離を行ない, その型別を実施してき た。また，同時期に大阪市立桃山病院に入院した 猩紅熱患者の咽頭より分離した $\mathrm{A}$ 群溶血レンサ球 菌の型別も行なつてきた。そ結果, 今回, 健康 学童と猩紅熱患者のそれぞれの型別を年度を追つ て比較し，その動態を検討することができた。

なを, ここに言う健康学童とは, 検査当日, 登 校して扣り菌検索に支障をきたさなかつた者をい ろ.

\section{II. 対 象}

大阪市の中心部, 北区にある「U小学校」と, 東北部の東淀川区に位置する「S小学校」の 2 校
の全学童を対象とした。

前者は, 大阪駅の直ぐ北側のターミナル繁華街 の真只中にある小学校で, ビル街のなかにはさま れて和り，この研究を始めた頃の学童数は約 300 人であつたが，最近の過疎化により100名前後に 減少している。ただし, 都会の中央にあるためか, 学校の環境は別として, その衛生教育, 衛生状態 は極めて良く, この16年間の検索中に健康優良校 に指定されたほどである，そのため，この学校か らは; 少なくとも我々の検索中は, 猩紅熱, 急性 腎炎, リウマチ熱等の発生は皆無であつた。

これに対し，後者は1962年の大阪市内に和け る猩紅熱流行の中心となつた地域にある小学校 で, 場所は都心部よりやや離れて和り, 環境とし ては附近は住宅街が多く, 一部に商店街もみられ る. 前者の学校とは反対に, 近年, ドーナツ現象 により学童数が増加の傾向にあり, 検索当初の学 童数は700名前後であつたものが，1977年には約 1200名になつている.

つまり,この 2 校は, かつて猩紅熱の流行を経 過した地域と, その全く発生をみなかつた地区の それぞれの代表ともいうべき小学校である. 
この 2 ケ所の小学校の健康学童と, 桃山病院に 入院した猩紅熱患者の咽頭より分離した $\mathrm{A}$ 群溶血 レンサ球菌の三者の異同を年度を追いながら比較 検討した。

なを，検索年度としては，S 小学校は1962年か ら1977年まで16年間, 毎年 1 回, 12月に実施し, U 小学校は1964年 9 月から, 1977年 8 月まで14年間, 月 1 回，ただし1976年と1977年は 2 ケ月に 1 回実 施した。猩紅熱患者の検索は1962年 1 月から1977 年 8 月まで行なつた。ただし，猩紅熱患者から分 離した菌型の推移をみるための年度別の分け方と しては毎年 9 月から翌年 8 月までを 1 年度とし た。これは季節的にみて猩紅熱患者の発生が著減 する夏期を以つて，年度交代としたわけである。

ただし，各年度の猩紅熱患者及び学童の比較の ためには，猩紅熱患者では上記年度で代表し， $\mathrm{S}, \mathrm{U}$ の 2 小学校は 12 月の検査成績によつて比較 した.

\section{III. 方 法}

溶血レンサ球菌の分離は, 咽頭粘液を隇菌綿棒 で採取後, 直ちに $5 \%$ ウマ脱線維血液加寒天平板 培地に直接表面塗洙を行なつた. $37^{\circ} \mathrm{C} 1$ 夜培養後, $\beta$ 溶血を指標として集落を選択し, Todd-Hewitt broth (Difco) 飞純培養後, $-20^{\circ} \mathrm{C}$ 凍結保存し た。即ち, 今回の実験に於いては, 毎回の検出率 の比較をる検討するため, 表面培養のみを実施 し, 混釈培養や Pike 培地等を使用しての増菌は 行なわなかった。

群別及びA 群型別は Lancefield の毛細管沈降 反応 ${ }^{12)}$ によつた。ただし，A群の型別について は, 近年の我が国に於ける主要流行菌型とされて いる1,3,4,6,12型の各型についてのみ実施した。

なを, 免疫血清作成 ${ }^{1)}$ に使用した菌株は予研分 与の次のものである.

$\mathrm{A}$ 群 1 型 : T1/119/16

3 型 : D $58 \times / 11 / 1$

4 型 : $55-16$

6 型: $\mathrm{S} 43 / 137 / 4$

12型 : T12/36/1

これらに反応しないA群菌は, 総べて UT (un-typable) とした。従つて, UT とは上記 5 つの型以外の菌も指すが，なかには，たと劣これ らに一致すると考えられる型であってもその菌の M抗原が減弱ないしは脱落しているため抗血清に 反応しないものも含まれるわけである.

\section{IV. 成 績}

1. 猩紅熱患者の咽頭分離 $\mathrm{A}$ 群溶血レンサ球菌 の型別の推移 (Fig. 1. Fig. 4)

健康学童の溶血レンサ球菌の型別の傾向を知る ため，まず1962～1977年の 16年間にわたり桃山病 院に入院した猩紅熱患者の咽頭から分離された $\mathrm{A}$ 群溶血レンサ球菌の型別の推移を検討した（Fig. 1).

なお，年度別の推移であるが，この検索の開始 は1962年の 1 月からであるため, Fig. 1 に示す 如く最初の年度は1962年 1 月から 8 月交でとし, その次からは当初に述べた如く, 9 月から翌年 8 月を各 1 年度とした。

1962年は前年の後半から大阪市内に猩紅熱患者 の発生 ${ }^{3)}$ が目立ち始め，1962年の夏を越しても患 者発生の減少の気配は見られず, むしろ増加の傾 向を示し1962年10月から翌1963年 3 月に最も多く の患者が大阪市内にみられた。この年度の流行菌 型は $\mathrm{A}$ 群 6 型 ${ }^{3}$ によるものであり, 分離株500株 中 $84.8 \%$ の比率を占めていた。この時の流行は大 阪に於いては太平洋戦争後では最高のものであり 対人口10万比でみると1962年は $15.9 ， 1963$ 年は 22.1を示した.

やがて，さしもの猩紅熱の猩獭の火も終息する とともに，患者数も年間 100 名前後となり，その 後の大阪に於ける猩紅熱は減少の一途を辿つた。 菌型も1963年の終り頃から出現し始めたA群 4 型 が 6 型と交代し主要流行菌型となつた。特に, 1964年 9 月～1965年 8 月には半数強の $50.4 \%$ を占 め最も優位となつている。しかしながら，1965年 9 月から1966年 8 月の間には，患者の間に再び 6 型が増加し始め, 各菌型中では最も多く $46.7 \%$ が 分離され，1966年 9 月から1967年 8 月には $51.5 \%$ と過半数を占めるに至つた。 このよらな患者数 の減少のなかにみられた 6 型の再優位は1969年 8 

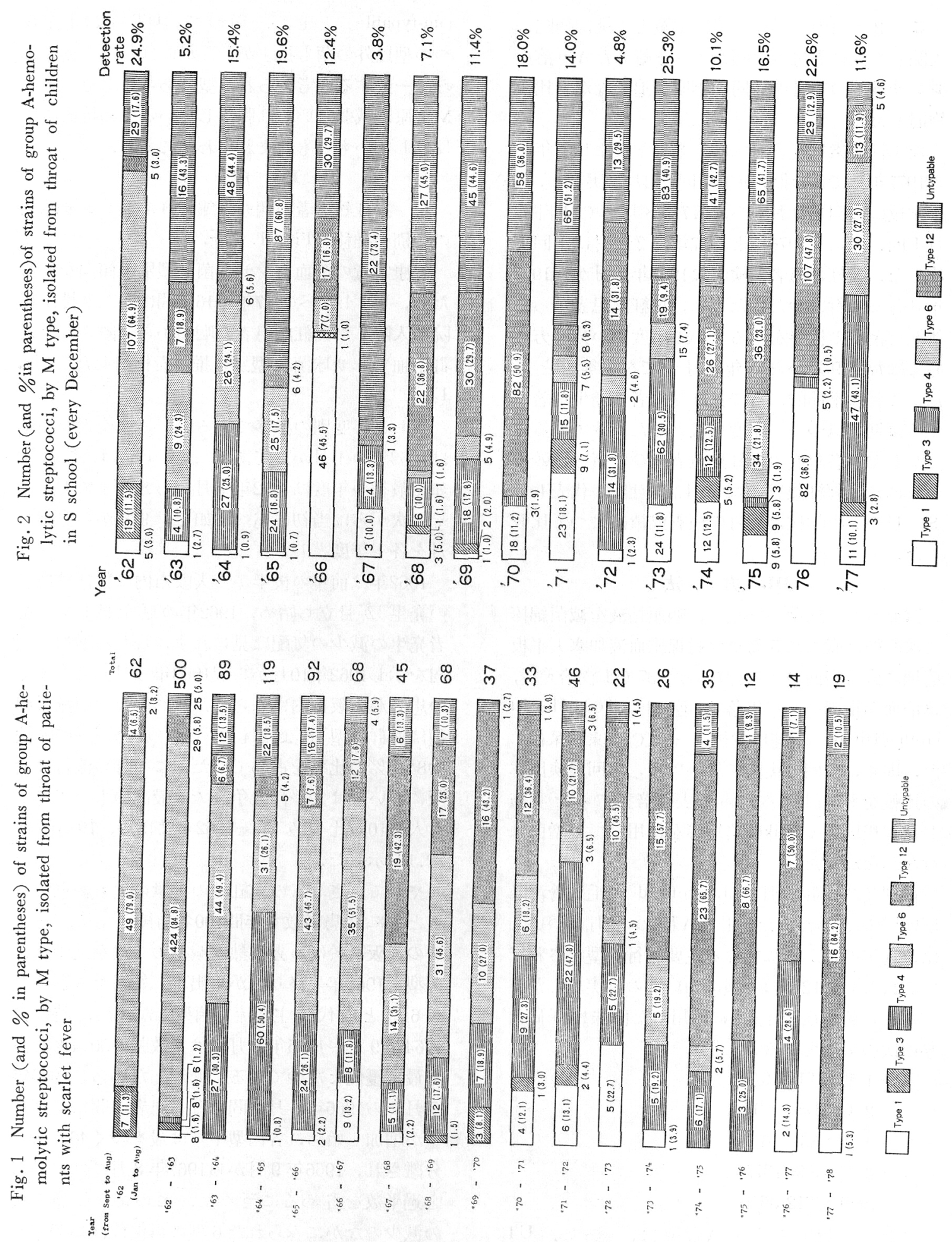


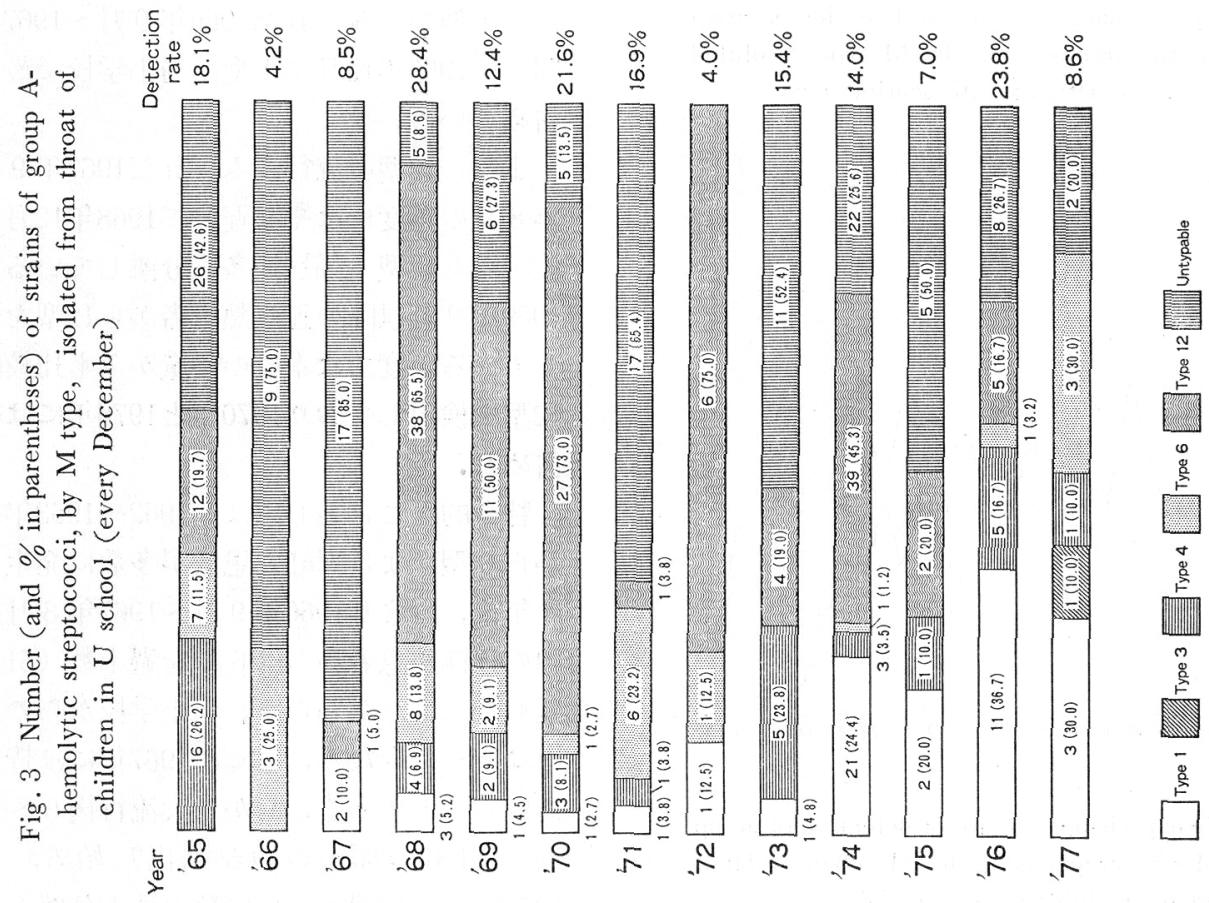

月まで続くものの，午の間に1967年 9 月〜 1968年 8 月には, 前年度から増加の徵候の見られた 12 型 が突如最多分離株 (43.2\%) となつた。 もつ も, この頃の年度より年間分離株は50株以下の少 数之なつている. 以後は, 多少の増減はあるもの の, つまり1971年 9 月〜 1972年 8 月の 4 型最多の 年度を除いては，猩紅熱患者数は減少していきな がらも，12型の全盛時代へ之移行してきた。

勿論，その間に 1 型の増加した年度（1972年 9 月〜1973年 8 月）もあるが，最多分離株とはなり 得ず，また 3 型はこの16年間では大阪地方の猩紅 熱からは多くは分離されなかつた。

以上の如く, 大阪に於いてはA 群 6 型, 4 型, 12型が，交代しながらそれぞれの年度の優位株之 なつて16年間を経過してきた。しかも，全般的に 言觉ることはUT の少ないことが特徵である。

2. 健康学童の咽頭分離 $\mathrm{A}$ 群溶血レンサ球菌の 型別の推移

1) S 小学校 (Fig. 2, Fig. 5)

先に述べた如く, この小学校は1962年〜1963年 の大阪市内の猩紅熱流行地区の中心をなつた学校
の一つでめる。即ち，この時には15名の猩紅熱患 者が当小学校より桃山病院に入院し, その全員か ら入院時にA 群 6 型を分離している。

それを反映してか，1962年12月の全校学童を対 象にしての咽頭からのA群溶血レンサ球菌の分離 率は $24.9 \%$ と他の年度に比較して高くなつてい る。しか子, 6 型の占める比率が分離株中064.9 \%で㟧ったこのことは, たとえ猩紅熱の発疹出 現といら形の発病は無くても, A 群 6 型の保菌者 といら形としての流行菌型の侵淫度の激しからた ことを物話つている。をた, 他の菌型も若干分離 しているが，この年度の特徵は16年間を通じて UT が最も少数でありたことである。

この地区の患者の発生が年々減少してくるとと もに, 当小学校に於沙る咽頭からのA群溶血レン サ球菌の検出率も溸減し，1973年と1976年を除い ては20\%を越光ることは無く，多くは10\%台であ り，ときには3.8\%（1967年）4.8\%（1972年）之 いら低率の年もあった。

しかも, 猩紅熱患者の減少とともに, UT の占 める比率が增加してきたことが特徵である。 
Fig. 4 Yeary change in rate of detection of group A-hemolytic streptococci, by $\mathrm{M}$ type, isolated from throat of patients with scarlet fever

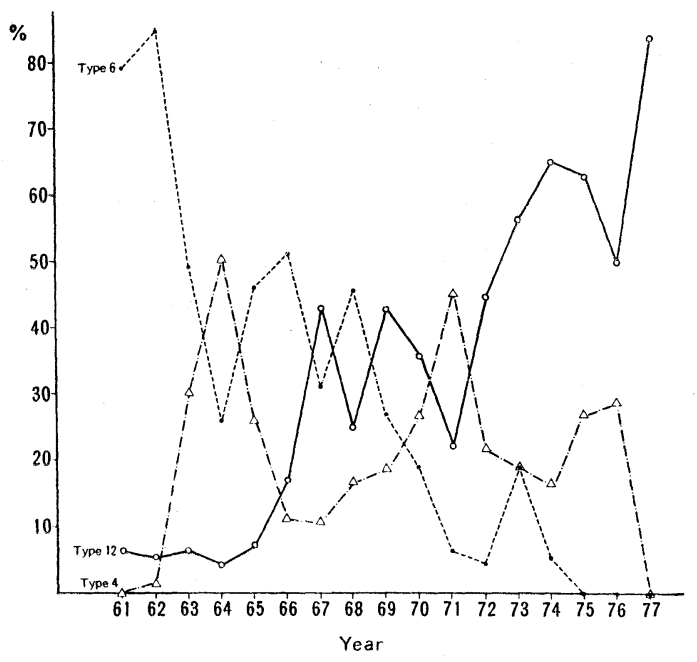

Fig. 5 Yearly change in rate of detection of group A-hemolytic streptococci, by $\mathbf{M}$ type, isolated from throat of children in $\mathrm{S}$ school

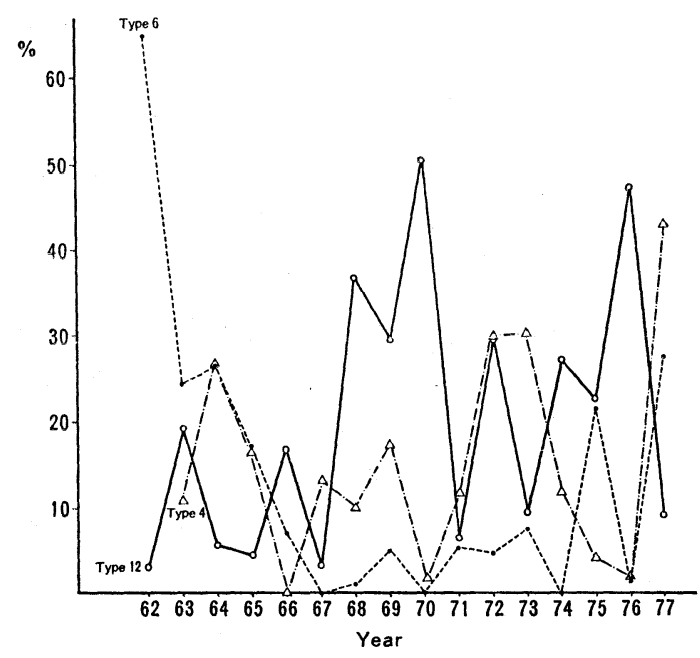

ただ，型別可能であつた菌について検討する と, 少数ではあるものの猩紅熱の流行菌型とほぼ 一致した型別の推移を示している.

即ち，4 型の流行した1964年 9 月～1965年 8 月 そ1971年 9 月～1972年 8 月のそれぞれの年度，つ まり1964年と1972年の各12月検索の結果では，当 小学校から 4 型を最も多数に分離し, 猩紅熱患者
から 1 型の分離された1966年 9 月〜 1967年 8 月の 間では1966年12月に 1 型が当小学校で最も優位を 占めている。

また，12型の流行がみられた1967年 9 月〜1968 年 8 月の年度にはやや遅れて1968年12月に当小学 校からも12型を最も多く分離している.さらに 1969年 9 月以降の猩紅熱患者から12型を多く分離 している年度では本校の学童からも比較的多数に 12型を検出しており1970年と1976年には約半数を 占めた。

特徵的なこととしては，1962～1963年に当地区 から 6 型による猩紅熱患者が多数に発生した以後 の年代，つまり1966年 9 月～1967年 8 月に大阪市 内の猩紅熱患者からは 6 型を過半数 $(51.5 \%)$ 分 離したにもかかわらず, 当小学校からの 6 型の検 出は極めて少なく，とくに1967年には皆無になつ ていることである.しかし大流行後 6〜7年を経 過した1969年頃から再び検出し始め，14年目の 1975年には12型とほぼ同数の株を分離し得るに至 つた。

1 型は1966年に最多を占めた後，1976年に再び 増加の傾向を示した。

3 型は各年度に於て若干分離されたが，この16 年間, ついに優位を占めるには至らなかった。

2) U小学校 (Fig. 3, Fig. 6)

当小学校は, 既述した如く 1962 1963年の猩紅 熱流行に際しても，またその後に於いても1例の 猩紅熱患者の発生もみられなからた。

ただ，当小学校の全学童の咽頭からの A 群溶血 レンサ球菌の検索が1965年から実施されたため, 1962 1963年の猩紅熱流行時の当小学校の成績は 不明である。

1965年以降のA群溶血レンサ球菌の検出率は最 高 $28.4 \%$ から最低 $4.2 \%$ であつた。

菌型については, 当小学校の型別の推移は $\mathrm{S}$ 小 学校と割合に似ている。ただ， S小学校よりも UT の比率が多くみられたことが特徴である。し かしながら1968年にはUT が反対に非常に少なく なり，12型が65.5\%を占めたこと，さらに1970年 には12型の割合が増加して73.0\%となつたこと， 
Fig. 6 Yearly change in rate of detection of group A-hemolytic streptococci, by $\mathbf{M}$ type, isolated from throat of children in $U$ school

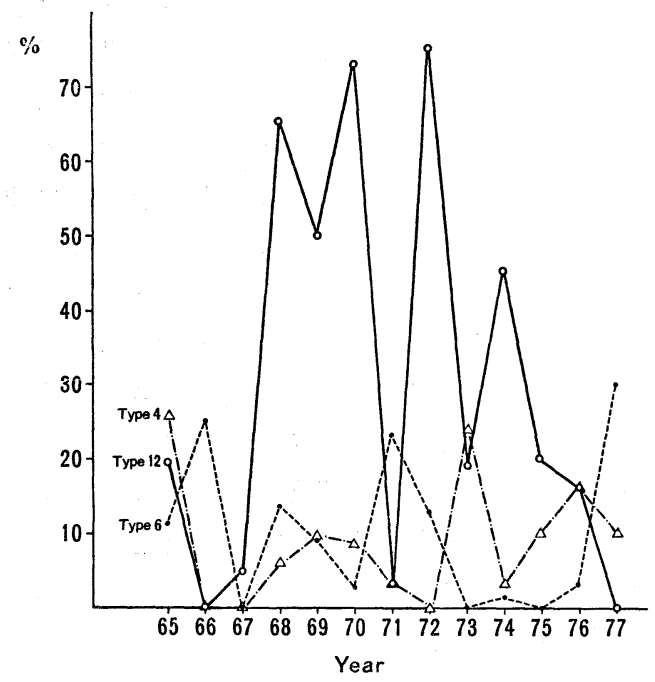

そして 1972年には分離株は少数ではあるものの UT が無く 12 型が75\%を占めるに至つた.

このことは，1967年 9 月〜1968年 8 月，1969年 9 月〜 1970年 8 月及び1974年 9 月〜 1975年 8 月に 猩紅熱患者から 12 型を最も多く分離したことを良 く反映しているものと考学られる。

しかし，その比率が $\mathrm{S}$ 小学校よりもはるかに多 いことは，明らかな臨床的な所見はないものの， 軽度の咽頭炎等の微症状があつたものとも考光ら れる。

6 型については，全分離菌株数が少ないため $\mathrm{S}$ 小学校ほどの明瞭な傾向は認められないが，猩紅 熱患者に拉ける 6 型の再流行のみられた1966年に はUT 以外は総べて 6 型であつた。その他, 1971 年を中心に1968年から1972年に検出されている.

4 型も同様, 少数株ではあるが, 猩紅熱患者の 間に 4 型の流行のみられた1965年及び1973年に多 く分離された。

1 型については1967年以後, 割合によく検出さ れ，とくに1974年と1975年に目立つてきて拉り， 1976年には最優位株となり，1977年に引き続いて いる。

3 型は，この検索中 1 株も分離されなかつた。

\section{v. 考 案}

$\mathrm{A}$ 群溶血レンサ球菌は健康学童の咽頭からもし ばしば分離されることが多くの報告者によつて知 られている。

しかし，その多くは長年月にわたつて検討され たものではなく，また同一集団を追跡調査したも のは極めて少ない，長期間の例としては, Zanen ${ }^{4}$

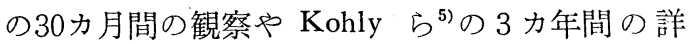
細な検討及び野口ら ${ }^{6)} 2$ 力年間にわたる連続調 査がある.今回我々は，16年間にわたつて $\mathrm{S}$ 小学 校を，また14年間に及んでU小学校のそれぞれの 全健康学童を対象に，咽頭上り $\mathrm{A}$ 群溶血レンサ球 菌の分離を行ない型別を実施し，同時に猩紅熱患 者の咽頭分離の $\mathrm{A}$ 群溶血レンサ球菌の型とを対比 し検討を加えた。

$\mathrm{A}$ 群溶血レンサ球菌の咽頭からの検出率は報告 者によつてかなりの差異がある。即ち, 培湌条件 によつて異なり，Pike 培地等の增菌培地を使用 した際には割合に高い検出率となつている。我々 は，年度別による検出率の比較をするため，増菌 培地は使用せず，咽頭粘液を直接，血液加寒天平 板培地に塗沫して菌の分離を行なつた。

その結果，S小学校では $3.8 \%$ から $25.3 \%$ の幅 をもつて，またU小学校は $4.2 \%$ か $28.4 \%$ 差 をもつて検出率の高低が年度によつて認められ た. 即ち，猩紅熱の大流行のあつた年度 (1962 年) の, しかも流行地域内の $\mathrm{S}$ 小学校での検出率 は他の年度に比し，かなりの高い值であつた。こ のことは，猩紅熱の流行地域には発疹出現という 臨㦿的な顕性発病はなくても, 不顕性感染といら 形で，かなりのA群溶血レンサ球菌の浸淫があつ たものと考えられる。

ただし，1968年のU小学校 (28.4\%)，1973年 の $\mathrm{S}$ 小学校 (25.3\%) の場合は, 猩紅熱といら形 での溶血レンサ球菌感染症の流行は存在しなかつ たが，感冒様上気道疾患等の臨床的には軽度の咽 頭充血等の微症状をもつて, それぞれの地域での 流行があつたものとも推定される。

菌型の点を検討すると, 健康学童の咽頭から分 離された $\mathrm{A}$ 群溶血レンサ球菌は猩紅熱患者から検 
出された菌型とほぼ良く似た傾向を示していた。 両者の間での顕著な差異としては UT が健康学 童に多いことである。これは今回の我々の型別 は, 毛細管沈降反応 ${ }^{2)}$ で行われたため, 型特異物 質でありかつVirulence factor とされるM抗原 が健康者では減弱あるいは脱落していることと想 定される. 従つて, もし $\mathrm{T}$ 抗原による凝集反応 ${ }^{6}$ によつたならば，なを多くの，あるいは殆んどの 菌が型別可能となつていたかも知れない。

一方, 猩紅熱患者から分離された $\mathrm{A}$ 群溶血レ ンサ球菌は各年度とも UT が少なかった。乞の 内容を知る目的で1967年 9 月〜 1968年 8 月に UT であつた 5 株を予研に送附して型別を依頼したと ころが，そのうち 1 株のみが毛細管沈降反応によ つて18型と判定されただけで，他の 4 株は型別不 能であつた。恐らく，その年度の主要流行菌型で あつた 12 型もしくは 4 型の型特異のM抗原が脱落 していたものと考觉らる。

このことからみても健康者から分離される UT の多くは, Virulence factor であるM抗原が減弱 もしくは脱落していたものと考光ても良い。つま り, 主要流行菌型以外の菌型といらょりも流行菌 型のM抗原が減弱しているために反応しないもの であると考えられる。

さて，大阪に於ける流行菌型の推移であるが， この16年間に関する限り, 猩紅熱患者からも健康 学童からもA群 6 型, 4 型, 12 型が交代して多く の比率をもつて検出された。 1 型と 3 型も年度に より多少は分離されたが主要流行菌型とはならな かつた。このことに関し児玉 ${ }^{8)}$ は我が国での溶血 レンサ球菌の流行の主役を演じているのはA群 4 型, 6 型, 12 型など比較的少数の菌型に限られて いると述べていることと全く一致する. 同様のこ とは永瀬 ${ }^{9)}$, 宮本ら ${ }^{10)}$ の報告にみられ，その傾向 は 3 回 $^{11211^{13)}}$ の研究班の 報告書からもらがかえ る. 勿論, 菌の分離された地区, 年度によつて例 外的な報告 ${ }^{14) 15) 16)}$ も散見される。

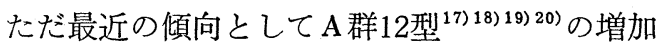
してきたという報告が多く，大阪の我々の成績と 一致している.
1962～1963年に 6 型による猩紅熱の大流行がみ られた地区 $\mathrm{S}$ 小学校からはその後, 年を追うて $\mathrm{A}$ 群 6 型が減少し，1968年 9 月〜1969年 8 月の 6 型 再流行の時には $\mathrm{S}$ 小学校からは 6 型の分離は極め て少なく，1970年には皆無になり，その次の年か ら再び検出されるょうになつた。即ち, この地区 には激しい 6 型の大流行のため地区住民にも不顕 性感染がかなりあり，そのため 6 型に対する免疫 がかなり強く出来ていたためと考えられる，その 大流行以後に誕生した小児が, 就学する頃には学 校児童の 6 型に対する免疫力も低下し再び 6 型を 検出し得るようになつたと考えられる.

興味あることは 1 型の変遷である。即ち， S 小 学校で1966年に 1 型が最優位 $45.5 \%$ を占め, U小 学校でも1974年には $24.4 \%$ と増加し，1976年には $\mathrm{S}, \mathrm{U}$ 両小学校ともに36\%台になつている。こ のように，1型は大阪に於いて猩紅熱患者からは 未だ主要流行菌型とはなつていないものの, 健康 学童間には時として増加の傾向をみせている。こ のことは宮本ら ${ }^{9)}$ の報告による近年の裏日本に於 ける 1 型の比較的高率な動きの影響かどらか今後 の動向が注目される。

\section{VI. 結 語}

1962年以後, 最近16年間にわたり大阪市内の $\mathrm{S}$ 小学校, 1965年以後, 13年間に及びU小学校のそ れぞれの全学童, ならびに同期間に於ける猩紅熱 患者を対象に咽頭より $\mathrm{A}$ 群溶血レンサ球菌の分離 を行なつた。

1. 検出率は, S 小学校では最高 $24.9 \%$ から最 低3.8\%まで，U小学校では28.4\%から4.2\%まで の幅がみられた。これは，一つには猩紅熱の流行 のあつた年度に, 他は猩紅熱以外の溶血レンサ球 菌感染症の流行のあつたと推測される年度に，そ れぞれ健康学童からも高い検出率が示されたと考 えられる。

2. 菌型の点では, 全般的には学童の咽頭分離 $\mathrm{A}$ 群溶血レンサ球菌の型別は猩紅熱患者の菌型と よく似た推移を示した。異なる点としては，学童 には UT. (Untypable) が多くみられたことであ る。 
3. 大阪での $\mathrm{A}$ 群溶血レンサ球菌の流行は, 6 型, 4 型, 12型が主要流行菌型として交代して出 現している。しかし，1962〜1963年に6 型による 猩紅熱の大流行がみられた地区の $\mathrm{S}$ 小学校から は, その後の大阪の 6 型による猩紅熱の再度の流 行（1968年 9 月〜1969年 8 月）に際しては， 6 型 の検出率は極めて低度であつた。

4. 1 型については, 猩紅熱患者に於ては最多 分離株とはならなかつたが, 健康学童からはとき として多く分離され, 最優位株となつた年度もあ つた。

（本論文の要旨は第37一48回日本伝染病学会総会及び 第49-52回日本感染症学会総会に於て発表した。）

\section{文 献}

1) Lancefield, R.C.: A serological differentiation of human and other groups of hemolytic streptococci. J. Exp. Med., 57: 571-595, 1933.

2) Swift, H.F., Wilson, A.T. and Lancefield, R.C.: Typing of group A hemolytic streptococci by $\mathbf{M}$ protein reaction in capillary pepettes. J. Exp. Med., 78: 127-133, 1943.

3) 中島邦夫, 広済幸男, 赤尾満, 中村睡三, 中 村 稔, 谷垣利幸: 最近の大阪地方における 猩紅熱の流行について一特に溶連菌を中心と する疫学的考突一日本伝染病学会雑誌, 38: 181-192, 1964.

4) Zanen, H.C., Ganor, S. and Van Toorn, M.J. : Continuous study of hemolytic streptococci in the throats of normal children, adults and aged men. Amer. J. Hyg., 69: 265-273, 1959.

5) Kholy, A.El., Sorour, A.H., Houser, H.B., Wannamaker, L.W., Robins, M., Poitras, J.M. and Krause, R.M.: A three-year prospective study of streptococcal infections in a population of rural Egyptian school children. J. Med. Microbiol., 6: 101-110, 1973.

6) Noguchi, M., Wakamatsu, Y., Chisawa, R., Kusama, H., Ohashi, M., Fukumi, H., Tadokoro, I., Kudo, M., Yoshioka, M., Kasuga, T. and Hirayama, I.: Immunological significance of antistreptolysin $\mathrm{O}$ (ASL) in streptococcal infections. II. A two-year study of steptococcal infections in primary school children. Jap. J. Med. Science and Biology,
15: 189-197, 1962.

7) 宮本 泰 : レンサ球菌, 臨床検査, 49 : 10851091, 1969.

8) 児玉 威: 溶連菌感染症と菌型分布の変遷. 感 染症学雑誌, 44：199-202, 1970.

9) 永瀬金一郎：M型別法による $\mathrm{A}$ 群溶血連鎖球 菌の菌型分布に関する研究. 感染症学雑誌, 47： 497-500, 1973.

10) 宮本 泰, 滝沢金次郎, 松島章吾, 浅井良夫, 岡崎則男：A 群連鎖球菌の菌型分布（196970年). 感染症学雑誌, 47：501-502, 1973.

11）溶血性連鎖球菌感染症の流行菌型と合併症と の関係についての研究: 昭和 39年度厚生科学 研究班報告書, 昭和39年 (1964).

12) 猩紅熱の診断, 特に類似疾患との鑑別および 各種抗生剂療法の比較検討に関する研究：昭 和 40 年度厚生省医療研究助成補助金による研 究報告, 昭和 41 年 (1966).

13）猩紅熱類似疾患の診断及び治療に関する研究： 昭和 43 年度厚生省医療研究助成補助金に上る 研究報告, 昭和43年 (1968).

14）御策納孝次郎, 平山顕, 吉田律子：最近猩 紅熱患者から分離した溶連菌の薬剤感受性特 にエリスロマイシン耐性菌の出現について. 感 染症学雑誌, $46: 80-82,1972$.

15）清水長世, 御簾納孝次郎, 柳下德雄, 川上 稔: 某小学校の 1 学級に発生した猩紅熱とこれに 関する疫学的および臨床的研穷。日本伝染病 学会雑誌, 42:271-286, 1969.

16) 山田俊彦, 小酒井 望, 新田一昭, 塩川優一： 埼玉県戸田市における学童呐頭溶連菌の疫学. 感染症学雑誌, 52 : 98-101, 1978.

17) 岡田 淳, 只野寿太郎, 伊藤機一, 宮本 泰, 宮里不二彦：学童に打咽頭溶連菌の研究 (第 2 報). 感染症学雑誌, 47 : 101-105, 1973.

18) 斉藤 譲, 甲賀正聡, 井脇宜弘, 石飛了:子, 宮本 泰: 立川市内某幼雅園における猩紅熱 の集団発生について. 感染症学雑誌, $48: 8-$ $16,1974$.

19）片山淳, 岩崎明, 川口信行, 田中一成, 真 鍋和行：山口県における溶連菌の分布調査, 特 に豊田町 $\mathrm{N}$ 保育園で流行した猩紅熱樣疾患を 中心として. 感染症学雑誌, 51：583-589, 1977.

20）丸山静男, 藤田晃三, 滝本昌俊, 吉岡一, 佐 竹良夫, 富樫 要, 田坂芳郎, 村井貞子, 稲積 温子 : 最近 1 年間に臨床材料より分離した $\mathrm{A}$ 群溶連菌の血清型と抗生剂感受性について. 感 染症学雑誌, 50：173-179, 1976. 
Yearly Epidemiological Survey of Group A-hemolytic Streptococci

Isolated from Throat of Healthy Children

Part I Analysis by M Type

Kunio NAKAJIMA

Osaka Municipal Children's Hospital (Formerly belonged to Osaka Municipal

Momoyama Hospital of Communicable Diseases)

Toshiyuki ADACHI and Meguru HADA

Osaka Municipal Momoyama Hospital of Communicable Diseases

Yearly survey of healthy children in two primary schools in Osaka city and scarlet fever patients, who served as the control for incidence of $\mathrm{M}$ type of group A-hemolytic streptococci for periods of some dozen years revealed:

1) The rate of detection of group A-hemolytic streptococci varied greatly with year, and ranged from $24.9 \%$ to $3.8 \%$ in $\mathrm{S}$ school and from $28.4 \%$ to $4.2 \%$ in $\mathrm{U}$ school. The maximum rate for $\mathrm{S}$ school is for the year of 1962 when scarlet fever was epidemic, and that for U school, for 1968 when most infections due to group A-hemolytic streptococci were unlikely to be scarlet fever.

2) The yearly change in $M$ type of group A-hemolytic streptococci isolated from the throat of healthy children coincided largely with that from patients with scarlet fever, except that the children carried untypable strains more frequently than the patients.

3) The major strains in $M$ type that repeatedly caused group A-hemolytic streptococcal infections included 6, 4, and 12. The rate of detection, in years 1968 and 1969, of M type 6 strain among the children of S school, which is located near the center of the 1962 to 1963 epidemic caused by M type 6 strain, was extremely low.

4) In no year was $M$ type 1 strain the most freguent organism among patients with scarlet fever, though it topped among healthy children in a couple of years during this survey. 